\title{
Does Masturbation Frequency Effect Sperm Parameters?
}

\section{Mastürbasyon Sıklığı Sperm Parametrelerini Etkiler mi?}

\author{
(1) Hasan Turgut ${ }^{1}, 2$, (1) Güner Kemal Özgür2 \\ ${ }^{1}$ Avrasya University Faculty of Health Science, Department of Nutrition and Dietetics, Trabzon, Turkiye \\ 2Medicalpark Karadeniz Hospital, Clinic of Urology, Trabzon, Turkiye
}

\section{What's known on the subject? and What does the study add?}

To date, no extensive research has been conducted on the relationship between masturbation and infertility directly in studies. We found that the frequency of masturbation during the teenage years may be related to infertility.

\begin{abstract}
Objective: To evaluate the relationship between male infertility and masturbation habits of patients who cannot provide a sperm sample. Materials and Methods: A total of 48 male patients aged 22-44 years who presented with complaints of primary infertility were included in the study. Patients who met the study criteria were requested to provide a spermiogram sample after a 3-7-days abstention from sexual relations. Sperm samples were surgically taken from patients who could not provide a sperm sample and pathology results of the samples from the testes were assessed. Patients with a surgically obtained sperm sample were named Group 1 and patients with no live cells found group 2. According to the parametric conditions of the data, the Independent Samples t-test or the Mann-Whitney U test were applied $(p<0.05)$.

Results: The rate of obtaining a sperm sample was statistically significantly higher in the group with a higher monthly frequency of masturbation. No significant difference was seen between the groups with respect to age $(p=0.81)$. There was a statistical significant difference between the

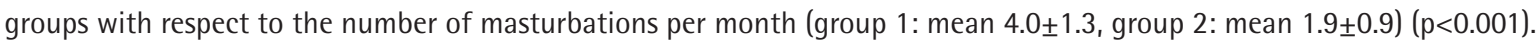

Conclusion: The results of this study showed that there could be a relationship between the frequency of post-adolescent masturbation and azoospermia, although this relationship is not scientifically explained.
\end{abstract}

Keywords: Azoospermia, Infertility, Masturbation

Öz

Amaç: Sperm örneği veremeyen hastaların mastürbasyon alışkanlığının erkek enfertilitesi ile olan ilişkisini değerlendirmektir.

Gereç ve Yöntem: Çalışmaya primer enfertilite şikayetiyle başvuran 22-44 yaş arası toplam 48 erkek hasta dahil edildi. Uygun koşullar sağlanıp hastalardan 3-7 günlük cinsel perhiz sonrası spermiyogram örneği istendi. Sperm örneği veremeyen hastalardan cerrahi yollarla örnek elde edildi ve testisten patolojik örnek yollanarak sonuçları değerlendirildi. Cerrahi işlem sonrası sperm örneği bulunan hastalar grup 1, canlı hücre bulunamayan hastalar grup 2 olarak sınıflandırıldı. Verilerin parametrik durumuna göre independent samples t-test veya Mann-Whitney U test uygulandı ( $<<0,05)$. Bulgular: Her iki grup karşılaştırıldığında aylık mastürbasyon sayısı yüksek olan gruptaki hastalardan sperm elde etme oranı daha yüksek bulunmuş olup istatiksel olarak anlamlı fark tespit edilmiştir. Gruplar arasında yaş açısından anlamlı fark gözlemlenmedi $(p=0,81)$, ancak gruplar arasında aylık

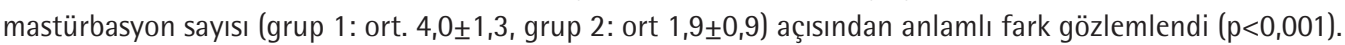

Sonuç: Bilimsel olarak açıklanmış olmasa da yapılan çalışmada ergenlik sonrası yapılan mastürbasyon sıklığı ile azospermi arasında ilişki olabileceği görülmüştür.

Anahtar Kelimeler: Azospermi, İnfertilite, Mastürbasyon

Correspondence: Hasan Turgut MD, Avrasya University Faculty of Health Science, Department of Nutrition and Dietetics, Trabzon, Turkiye; Medicalpark Karadeniz Hospital, Clinic of Urology, Trabzon, Turkiye

E-mail: drhasanturgut@hotmail.com ORCID-ID: orcid.org/0000-0001-9793-6734

Received: 02.11.2019 Accepted: 02.03.2020

Cite this article as: Turgut H, Özgür GK. Does Masturbation Frequency Effect Sperm Parameters? J Urol Surg 2020;7(3):200-203.

${ }^{\circ}$ Copyright 2020 by the Association of Urological Surgery / Journal of Urological Surgery published by Galenos Publishing House. 


\section{Introduction}

Infertility is defined as no pregnancy after at least 12 months of regular sexual relations according to the World Health Organization. It is seen in 10\%-15\% of married couples and in 30\%-50\% of these, the pathology is usually associated with the male $(1,2)$. Azoospermia is a condition in which there is no sperm in seminal fluid, this is seen in 1\% of the male population, and has been reported to be at the rate of 15\% in infertile males $(3,4)$. Semen analysis is required after abstention from sexual relations for 2-3 days when assessing male infertility (5). After putting in place all favorable conditions, if the patient is unable to provide an ejaculated sperm sample, the micro testicular sperm extraction (TESE) or testicular sperm aspiration (TESA) operation can be carried out. The micro TESE operation is a surgical operation first described by Schlegel in 1998 for patients with non-obstructive azoospermia $(6,7)$.

Masturbation is the stimulation of the erogenous zones of the sexual organs generally to the point of orgasm (8). Masturbation has been reported to have extensive effects on the mental status of women, with many authors claiming that frequent masturbation increases depressive symptoms independent of a decreased frequency of penile-vaginal coitus $(9,10)$. However, to the best of our knowledge, there is no study in literature of male masturbation. While a healthy sexual penile-vaginal relationship may be achieved in a physical and physiological aspect, frequent masturbation has a negative effect on a healthy sex life (11).

From a comprehensive screening of literature, no study was found to have studied the frequency of masturbation as a factor which could cause azoospermia. In addition, there is insufficient information related to the effect of masturbation habits on patients who cannot provide a spermiogram sample.

The aim of this study was to evaluate the masturbation habits of patients with primary infertility and patients who could not provide a spermiogram sample. The null hypothesis of the study was that there would be an association between patients who cannot provide a spermiogram sample and the masturbation habits of those patients.

\section{Materials and Method}

The study was approved by Ethical Committee (approval no: 122/2020). A total of 48 patients, aged 22-44 years, who presented at the urology polyclinic between 2014 and 2019 with the complaint of primary infertility and could not provide a sperm sample despite the provision of appropriate conditions in the hospital were included in the study. The patients were classified according to their level of education. A retrospective evaluation of the anamneses, procedures applied, and results of the patients included in the study was made. A spermiogram sample was requested from the patients after a period of 3-7 days abstinence from sexual relations. Laboratory values of follicle-stimulating hormone (FSH), luteinizing hormone ( $\mathrm{LH}$ ), prolactin, and testosterone was recorded. Patients were excluded from the study if they were using any drugs that could cause azoospermia, if they had any disease (hormonal or systemic) or were engaged in any occupation that could affect the sperm parameters, had atrophic testes or unilateral testis, were smokers, had any disease that could cause erectile dysfunction or ejaculation problems, or had never masturbated.

To motivate the patients who were unable to provide a sample on the first visit, they were called a second time and a sample requested. Those who could not provide a sample for unknown reasons underwent a micro TESA operation or percutaneous TESA. The sperm freezing procedure was explained to the patients and the type of operation was decided by the patient. MicroTESE was performed on 34 patients and TESA on 14 patients. Informed consent was gotten from all the patients. Both procedures were performed under general anesthesia and samples sent to the laboratory for evaluation at the same time, the procedure continued bilaterally with the results. In patients where no sperm was found, pathological sampling was applied.

Following the surgical procedures, patients with a sperm sample were classified as group 1, and patients with no live cells determined were classified as group 2 . The anamnesis taken from each patient was reviewed again and patients with insufficient information were called by phone and were asked the question, "how many times do you masturbate a month?." Responses were evaluated and monthly masturbation frequency was compared between the two groups. The patients applied with micro TESE or TESA were azoospermic and the specimens obtained were evaluated pathologically.

\section{Statistical Analysis}

Variables were shown as mean \pm standard deviation, median, and range values. Conformity of the data to normal distribution was evaluated with the Kolmogorov-Smirnov test and histogram. Then, according to the parametric conditions, the Independent Samples t-test or the Mann-Whitney $U$ test were applied. All statistical analyses were made using SPSS version 20.0 software (Chicago, IL, USA). A value of $\mathrm{p}<0.05$ was accepted as statistically significant.

\section{Results}

Group 1 comprised of 21 patients with a mean age of $30.3 \pm 5.3$ years (range: 23-42 years), and reported mean frequency of masturbation as $4.0 \pm 1.3$ times per month (range: $2-6)$. Group 2 comprised of 27 patients with a mean age of $29.9 \pm 5.9$ years 
(range: 21-44 years), and reported masturbation frequency of mean $1.9 \pm 0.9$ times per month (range: $0-4)$ (Table 1$)$. The marriage periods of the two groups were 17.8 and 18.1 months respectively. When the two groups were classified according to the level of education, no significant difference was observed between the groups.

Before the procedure, scrotal ultrasonography was done to all patients. No difference was observed between the groups in respect of testis size and blood hormone levels $\left(\mathrm{FSH}, \mathrm{LH}_{1}\right.$ prolactin, testosterone). No significant difference was observed between the groups with respect of age $(p=0.81)$. A statistically significant difference was determined between the groups with respect to the mean number of masturbations per month $(\mathrm{p}<0.001)$.

The specimens taken from the azoospermic patient who underwent the microTESE or TESA were sent for pathological examination. The results were evaluated as Sertoli cell only in 44 testis units, testis tissue showing hypospermatogenic activity in 30 units, and atrophic testis tissue with germ cells present but no spermatogenic activity in 22 units (Table 2).

\section{Discussion}

The results of the study confirmed the null hypothesis that there is an association between patients who cannot provide a spermiogram sample and the masturbation habits of those patients. Although there was no significant difference between groups 1 and 2 with respect to age, a statistically significant difference was seen with respect to the frequency of masturbation before marriage. The incidence of azoospermia differs according to genetic differences, geographic region, and type of employment, lifestyle, and dietary habits (12). Genetic causes resulting in infertility include Klinefelter syndrome, $Y$ chromosome anomalies, and single gene anomalies. There may also be hormonal causes such as hypogonadotropic hypogonadism, anatomic reasons or orchitis, trauma or tumor surgery, cancer, radiotherapy or chemotherapy $(13,14)$. When the patients included in the current study were re-evaluated, these types of factors were not seen in any of the patient.

In a study by Ramadan et al. (15), 412 patients who presented with the complaint of infertility were separated into 2 groups. Group 1 comprised of patients who were not able to provide a sperm sample at the hospital for various reasons, but could give a sample at home during sexual relations or with the aid of vibrator stimulus, and group 2 included patients who had no difficulty in providing a sperm sample. The sperm concentration, sperm motility and normal sperm functions of group 1 patients were lower than those of group 2, but not to a statistically significant level. The duration of infertility was determined to be longer in group 1 than in group 2, and the partners of the patients in group 1 stated that the patients experienced extreme anxiety when providing the sample (15).

In a study by Saleh et al. (16), it found that sperm concentration and motility was reduced in sperm samples provided under stress and anxiety in the hospital. It was observed in our clinic that patients who could not provide a sperm sample in the hospital environment were generally anxious and lacking in self-confidence. The majority of these patients did not attend the clinic with their spouse, but came with their mother, father or sibling and were not able to speak about their problems themselves. The vast majority of patients who were not azoospermatic but could not provide a sample for various reasons (anxiety, hygiene, excitement, etc) attended the clinic alone or with their spouse. When sexual activity was questioned in the anamnesis, conflicting responses were obtained from patients who attended without their partner and an objective result could not be obtained. In some studies, male infertility has been determined to cause severe sexual dysfunction between couples, and it has been reported that there may be an association between male sexual dysfunction and reduced sperm motility (17). Pathologies accompanying ejaculation disorders such as premature ejaculation, non-ejaculation, retrograde ejaculation and erectile dysfunction may cause male infertility. Furthermore, infertility may be caused by some systemic diseases and the drugs used to treat those diseases (18).

\begin{tabular}{|l|l|l|}
\hline Table 2. Evaluation of the pathological results of the patients \\
\hline Pathological result & microTESE & TESA \\
\hline Sertoli cell only syndrome & 28 units & 16 units \\
\hline Hypospermatogenetic activity & 24 units & 6 units \\
\hline Atrophic testis & 16 units & 6 units \\
\hline TESA: Testicular sperm aspiration
\end{tabular}

Table 1. Data of the patients included in the study

\begin{tabular}{|l|l|l|l|l|l|l|l|}
\hline \multirow{2}{*}{} & \multicolumn{2}{|l|}{$\begin{array}{l}\text { Group 2 } \\
\text { (n=27) }\end{array}$} & \multicolumn{2}{l|}{ p } \\
\cline { 2 - 9 } & Mean \pm SD & Median & Range & Mean \pm SD & Median & Range & \\
\hline Age (year) & $30.3 \pm 5.3$ & 30 & $23-42$ & $29.9 \pm 5.9$ & 29 & $21-44$ & 0.81 \\
\hline Number of masturbations in a month & $4.0 \pm 1.3$ & 4 & $2-6$ & $1.9 \pm 0.9$ & 2 & $1-4$ & $<0.001$ \\
\hline SD: Standard deviation & \multicolumn{6}{|l|}{} \\
\hline
\end{tabular}




\section{Study Limitations}

There were some limitations of this study. The number of patients included in the study was relatively low. When the anamneses were evaluated, most patients had not given sufficient information about sexual life, erectile functions and masturbation habits because of embarrassment or unwillingness to answer, so objective results could not be obtained. As some information was received some patients over the telephone, the responses may not have been clear. There was no information about the frequency of sexual intercourse before and after marriage. When the study results were evaluated, it was clearly seen that the patients who could not provide a spermiogram sample had masturbated very infrequently. There is a need for further more extensive studies with more patients to evaluate different parameters.

\section{Conclusion}

According to the observations made during this study, it was seen that the majority of patients who could not give a sperm sample and who did not have sperm after surgery, also had communication problems. Even though the effect of frequent or infrequent masturbation on azoospermia has not yet been proven, it was concluded from the results of this study that patients with a low frequency of masturbation were azoospermic.

\section{Ethics}

Ethics Committee Approval: Ethics committee approval was received for this study from the Ethical Committee of Trabzon Medicalpark Karadeniz Hospital (approval no: 122/2020).

Informed Consent: Informed consent was gotten from all the patients.

Peer-review: Externally peer-reviewed.

\section{Authorship Contributions}

Concept: H.T., G.K.Ö., Design: H.T., G.K.Ö., Data Collection or Processing: H.T., G.K.Ö., Analysis or Interpretation: H.T., G.K.Ö., Literature Search: H.T., G.K.Ö., Writing: H.T., G.K.Ö.

Conflict of Interest: No conflict of interest was declared by the authors.
Financial Disclosure: The authors declared that this study received no financial support.

\section{References}

1. Revised glossary on Assisted Reproductive Terminology (ART). The International Committee for Monitoring Assisted Reproductive Technology (ICMART) and the World Health Organization (WHO) Revised Glossary on ART Terminology, 2009.

2. Tournaye HJ, Cohlen BJ. Management of male factor infertility. Best Pract Res Clin Obs Gyn 2012;26:769-775.

3. Willott GM. Frequency of azoospermia. Forensic Sci Int 1982;20:9-10

4. Spira A. Epidemiology of human reproduction. Hum Reprod 1986;1:111-115.

5. Smith, Roger P, Paul J, Turek MD. Netter Collection of Medical Illustrations: Reproductive System, The, 2th Edition Published January 1, 2011;462-466.

6. Schlegel PN, Su LM. Physiological consequences of testicular sperm extraction. Hum Reprod 1997;12:1688-1692.

7. Schlegel PN. Testicular sperm extraction: microdissection improves sperm yield with minimal tissue excision. Hum Reprod 1999;14:131-135.

8. Sayed SH. Masturbation: Scientific Evidence and Islam's View J Relig Health 2017;56:2076-2081.

9. Frohlich $\mathrm{P}$, Meston C. Sexual functioning and self-reported depressive symptoms among college women. J Sex Res 2002;39:321-325.

10. Cyranowski JM, Bromberger J, Youk A, Matthews K, Kravitz HM, Powell LH. Lifetime depression history and sexual function in women at midlife. Arch Sex Behav 2004;33:539-548.

11. Brody S, Costa RM. Satisfaction (sexual, life, relationship, and mental health) is associated directly with penile-vaginal intercourse but inversely with other sexual behavior frequencies. J Sex Med 2009;6:1947-1954.

12. Karabulut S, Keskin I, Pelin Kutlu P, Delikara N, Atvar Ö, Öztürk MI. Male infertility, azoozpermia and cryptozoospermia incidence among three infertility clinics in Turkey. Turk J Urol 2018;44:109-113.

13. Dohle GR. Male infertility in cancer patients: Review of the literature. Int J Urology 2010;17:327-331.

14. Poongothai J, Gopenath TS, Manonayaki S. Genetics of human male infertility. Singapore Med J 2009;50:336-347.

15. Ramadan A. Saleh, Geetha M. Ranga, Rupesh Rainaal all, Sexual dysfunction in men undergoing infertility evaluation: a cohort observational study. Fertılity and Sterility 2003;79:4.

16. Saleh RA, Ranga GM, Raina R, Nelson DR, Agarwal A. Sexual dysfunction in men undergoing infertility evaluation: a cohort observational study. Fertil Steril 2003;79:909-912.

17. Kızılay $F$, Şahin M, Altay B. Do sperm parameters and infertility affect sexuality of couples? Andrologia 2018;50.

18. Lotti $F$, Maggi M. Sexual dysfunction and male infertility. Nat Rev Urol 2018; 15:287-307. 